\title{
Bezpečné místo on-line pro Čechy v zahraničí: Bud'te sami sebou i v cizině
}

\author{
Michala Škrábová, Mila Della Briotta
}

\begin{abstract}
Abstrakt
Žít v cizině, adaptovat se na nové prostředí a novou mentalitu obyvatel a přijmout novou identitu cizince je všestranně náročný proces. Z toho důvodu vznikla Facebooková skupina „Češi v zahraničí: Sám sebou i v cizině”, která si klade za cíl vzájemnou podporu a inspiraci Čechů v podobné životní situaci v cizině.
\end{abstract}

Klíčová slova: adaptace, expat, mezikulturní rozdíly, duševní zdraví, psychická stabilita

\section{A safe on-line place for Czechs abroad: Be yourself even abroad}

\begin{abstract}
Living abroad, adapting to a new environment and a new mentality of people and adopting a new identity as a foreigner is a very psychologically demanding process by all means. For this reason, a Facebook group "Czechs abroad: be yourself even abroad" was formed. It aims to support and inspire Czechs in a similar life situation abroad.
\end{abstract}

Keywords: adaptation, expat, intercultural differences, mental health, psychological stability

Došlo do redakce: 26.9 .2021

Schváleno k publikaci: 27. 9. 2021

Počáteční těžkosti spojené se životem $\mathrm{v}$ zahraničí mohou způsobit značné pochybnosti o vlastních schopnostech, stres nebo pocity osamění. Současně procházejí zkouškou i mezilidské vztahy, některé se upevní a jiné zaniknou (Bruning, N. S., Sonpar, K., \& Wang, X. (2012), Cangià, F. (2017), Firth, B. M., Chen, G., Kirkman, B. L., \& Kim, K. (2014)). Lidé žijící v zahraničí se mění: někteří proto, aby v nové zemi obstáli a natrvalo se usadili, jiní, aby nasbírali hodnotné zkušenosti a obohatili svůj život po návratu do České republiky (Kraimer, M. L., Wayne, S. J., \& Jaworski, R. A. A. (2001). 
Pro všechny tyto jedince jsme založily Online psychologickou poradnu ${ }^{1}$ pro Čechy v zahraničí, jejíž součástí je také facebooková skupina „Češi v zahraničí: Sám sebou i v cizině”. Nabízíme v ní nejrůznější informace $\mathrm{k}$ tématům souvisejícím se životem v zahraničí, včetně zachování duševní pohody a duševního zdraví. Hlavním cílem naší online poradny je nabídnout specifický prostor ke sdílení nabytých zkušeností a z toho plynoucí podpůrný pocit sounáležitosti. Důraz klademe i na možnost sdílet témata $\mathrm{v}$ rodném jazyce, který usnadňuje př́stup $\mathrm{k}$ vlastním emocím a podporuje vznik nových kontaktů a vazeb.

Společně sdílíme své dobré i špatné zážitky z minulosti, přítomnosti i plány do budoucnosti. Reflektujeme myšlenky, pocity i situace, které dennodenně zažíváme, dáváme a získáváme zpětnou vazbu. Klademe si otázky, které vedou k zamyšlení nad konkrétními situacemi za účelem uvědomění si vlastních hodnot. Zda se v dané situaci cítím dobře, chci si situaci uchovat nebo ji změnit. Předáváme si zjištěné informace o tom, jak fungují systémy $\mathrm{v}$ různých zemích a můžeme si dát užitečné tipy napřs. s úřady, zdravotnictvím, školstvím apod. Lidé ve skupině nejvíce oceňují možnost sdílení s druhými, že v tom nejsou sami, že mohou nalézt spojence, který je pochopí a podpoří.

Každý pobyt v zahraničí začíná kulturním šokem: fakt, že je to tu jinak než v ČR, a naopak, když se lidé vrací ze zahraničí zpět do Čech, je nevyhnutelný. Opakujícími se tématy jsou zvládání stresu způsobeného novou rolí „,cizince”, reflexe vlastní identity a pocity osamění, smysl zahraničního pobytu, péče o děti a jejich vícejazyčná výchova, pracovní, rodinné a partnerské vztahy (Gupta, R., Banerjee, P., \& Gaur, J. (2012), Kraimer, M. L., Wayne, S. J., \& Jaworski, R. A. A. (2001), Pantelidou, S., Craig, T. (2006), Carraher, S. M., Sullivan, S. E., \& Crocitto, M. M. (2008), Firth, B. M., Chen, G., Kirkman, B. L., \& Kim, K. (2014), Presbitero, A. (2016), Stahl, G. K., \& Caligiuri, P. (2005)).

Níže je uvedeno několik příběhů z Online psychologické poradny pro Čechy v zahraničí, pro získání představy probíraných témat, které jdou více do hloubky, než je tomu ve FB skupině. Př́iběhy jsou upravené pro ochranu klientů.

Paní A. už žije pátým rokem v Anglii. Po narozeni dítěte se začala cítit velmi osamělá $i$ pres to, že se o ni is ditětem manžel a jeho rodina př́kladně starají a nestrádá ani ekonomicky. Probraly jsme spolu jeji predstavu sebe sama v roli matky v cizině. Společně jsme reflektovaly očekáváni a faktory, které ji od spokojeného naplněni mateřství vzdaluji a vyzdvihly ty zdroje, které jí budou v její nové roli nápomocné a na kterých müže dále stavět.

Pan K. si dělá starosti o svou českou manželku, u které se po prestěhování do USA začal projevovat výrazný pokles nálady a nespokojenost. Pan K. si dělá výčitky, že jí nedokázal zajistit slibované prostředi. Hledal psychologa online, který pomůže i na dálku. Zpočátku jsme se zaměrili na srozumitelnou partnerskou komunikaci, aby se rozkryly manželčiny nenaplněné potřeby. Později jsme nalézali cesty, jak pan K. může být manželce v rámci svých možností nápomocný a zbavit se svého pocitu selhání.

\footnotetext{
${ }^{1}$ Www.onlinepsycholog.eu
} 
Paní J. trpí pocitem smutku a nedostatkem energie. Cítí se sociálně izolována, v noci se budí s návaly úzkosti a její myšlenky se toči kolem návratu z Německa zpět do CZ. Velmi ji trápí také to, že rodina a prátelé jí dávají méně pozornosti, než by potřebovala. V průběhu poradenstvi jsme změnily postupně fokus z vnějšiho světa na svět vnitřní, rozpoznávání emocí a poselství, které sebou nesly. Zaměrily jsme se na posileni budování identity v novém prostředí a nalezení harmonického vztahu s minulostí v CZ.

Pan S. má pocit totálního vyčerpání z práce. Postupně mu ubývají volnočasové aktivity, prátelé i rodinu zvládá s vypětím sil. Zaměrili jsme se na jeho osobni hodnoty a cile. Přezkoumali jsme společně jejich realizovatelnost a cenu, za kterou jich lze dosáhnout. Našli jsme nové cesty, jak obstát ve švýcarské společnosti zaměrené na výkon a zároveň se nevzdat svých vlastních specifických zdroju energie a pocitu sebehodnoty.

Paní L. se přistěhovala za manželem do Španělska. Postupně ale procházi rozčarováním, hodně věcí je jinak, než si představovala. I manžel jako by byl ve svém prostředí jiný člověk, role se obrátily a cizinkou je nyní ve vztahu ona. Nejvíce ji trápí, že už druhým rokem nemůže najít práci ve svém oboru, na čemž jí velmi záleži. Postupně jsme zvažovaly různé scénáře: zůstat ve Španělsku, zvolit stř́lavý pobyt nebo se trvale vrátit zpět do CZ. Paní L. ve finále vyhodnotila jako pro ni nejzdravějši ř řsení návrat do CZ.

Jsme psycholožky, vystudovaly jsme psychologii na Karlově univerzitě a každá z nás se specializuje na jinou oblast psychologie. Nabízíme širokou paletu témat, na kterých s námi lze pracovat. Tam, kam nedohlédne jedna, má přehled druhá z nás. Naši klienti vnímají toto propojení specializací jako velkou přednost našeho on-line psychologického poradenství, které provádíme formou individuálních i skupinových konzultací.

Jste-li Čech, Češka v zahraničí a hledáte-li bezpečný prostor, kde byste získali spojence, kteří pochopí vaši situaci a zmírní pocity osamění, přijd’te do skupiny Češi v zahraničí: sám sebou i v cizině. Těší se na vás Michala a Mila.

\section{Literatura}

Bruning, N. S., Sonpar, K., \& Wang, X. (2012). Host-country national networks and expatriate effectiveness: A mixed methods study. Journal of International Business Studies, 43(4), 444-450. https://doi.org/10.1057/jibs.2012.5

Cangià, F. (2017). (Im)Mobility and the emotional lives of expat spouses. Emotion, Space and Society, 25, 22-28. https://doi.org/10.1016/j.emospa.2017.10.001

Carraher, S. M., Sullivan, S. E., \& Crocitto, M. M. (2008). Mentoring across global boundaries: An empirical examination of home- and host-country mentors on expatriate career outcomes. Journal of International Business Studies, 39(8), 1310-1326. https://doi.org/10.1057/palgrave.jibs.8400407 
Firth, B. M., Chen, G., Kirkman, B. L., \& Kim, K. (2014). Newcomers abroad: Expatriate adaptation during early phases of international assignments. Academy of Management Journal, 57(1), 280-300. https://doi.org/10.5465/amj.2011.0574

Gupta, R., Banerjee, P., \& Gaur, J. (2012). Exploring the role of the spouse in expatriate failure: a grounded theory-based investigation of expatriate' spouse adjustment issues from India. The International Journal of Human Resource Management, 23(17), 35593577. https://doi.org/10.1080/09585192.2011.645052

Kraimer, M. L., Wayne, S. J., \& Jaworski, R. A. A. (2001). Sources of support and expatriate performance: The mediating role of expatriate adjustment. Personnel Psychology, 54(1), 71-99. https://doi.org/10.1111/j.1744-6570.2001.tb00086.x

Pantelidou, S., Craig, T. (2006). Culture shock and social support. Social Psychiatry and Psychiatric Epidemiology, 41, 777-781. https://doi.org/10.1007/s00127-006-0096-5

Presbitero, A. (2016). Culture shock and reverse culture shock: The moderating role of cultural intelligence in international students' adaptation. International Journal of Intercultural Relations, 53, 28-38. https://doi.org/10.1016/j.ijintrel.2016.05.004

Stahl, G. K., \& Caligiuri, P. (2005). The effectiveness of expatriate coping strategies: The moderating role of cultural distance, position level, and time on the international assignment. Journal of Applied Psychology, 90(4), 603-615. https://doi.org/10.1037/00219010.90.4.603

\section{O autorkách}

PhDr. Michala Škrábová, Ph.D. - interkulturní psycholog

Vždy jsem se cítila dobře v kontaktu s cizinci. Během svého magisterského studia psychologie na Univerzitě Karlově jsem byla studijně na semestr v německém Regensburgu a v australském Melbourne. V rámci doktorátu jsem pobývala několik měsíců v Hirošimě, můj Ph.D. výzkum srovnával českou a japonskou mentalitu. Prošla jsem si několikrát adaptačním procesem v nové zemi a pokaždé si tvořila novou mezikulturní identitu.

Na UK jsem vyučovala více než 10 let Interkulturní psychologii pro Erasmus studenty psychologie a na Metropolitní univerzitě Praha 6 let Interkulturní komunikaci v byznysu. Hostovala jsem jako Erasmus učitel psychologie na italských univerzitách, převážně v Pise a v Bologni. Žiji s francouzsko-polským přítelem a dvěma malými dcerami ve francouzských Alpách.

Svým klientům, expatům z mnoha zemí, jsem pomohla překonat psychické potíže a připravila je na různé situace v mezinárodním prostředí. Přes 8 let se věnuji interkulturním a adaptačním tréninkům. Ráda pomáhám s osobním rozvojem a výzvami spojenými s cizí kulturou.

Konzultuji česky, anglicky a francouzsky. Domluvím se, ale nekonzultuji, italsky, německy a japonsky.

Kontakt: michala@onlinepsycholog.eu 
Mgr. Ing. Mila Della Briotta - psycholožka, psychoterapeutka a koučka

Přes polovinu života bydlím a pracuji v zahraničí, z toho dvě desetiletí ve Švýcarsku. První mezikulturní zkušenosti jsem získala bezprostředně po revoluci v německé stavební firmě v oddělení HR. V průběhu dalších let strávených v mezinárodním obchodě i v soukromém podnikání jsem zažila tlak konkurenčního prostředí a vliv stresu na své zdraví.

Zájem o prevenci vyhoření mě motivoval ke studiu klinické psychologie a k výcviku v koučování. Nyní se v Curychu vzdělávám v psychoterapii zaměřené na tělo. Praxi jsem absolvovala na psychosomatické klinice i v ambulantní psychiatrii. Propojení zkušeností ze zdravotnictví a $\mathrm{z}$ ostatních sektorů mi dodnes usnadňuje porozumění příčinám a následkům nejrůznějších psychických potíží.

Ráda se vzdělávám, cestuji, baví mě řešit problémy, chodit za kulturou i relaxovat. O svoje české kořeny pečuji pravidelně a s láskou. Český humor je pro mě dodnes nepostradatelným zdrojem pozitivních emocí i na jihu Švýcarska, kde s rodinou bydlím.

Ke svým klientům, kolegům, přátelům i rodině chovám hluboký respekt a vážím si jejich př́tomnosti. Své klienty motivuji, aby objevili, obstarali a udrželi si vše, co potřebují ke spokojenému životu v zahraničí. Pracovní techniky volím a kombinuji tak, aby se dokázali napojit na vlastní zdroje energie a uměli řešit vzniklé situace v adaptačním procesu.

Konzultuji v jazycích, ve kterých žiji: v češtině, němčině a italštině. Domluvím se, ale nekonzultuji, v angličtině a ruštině.

Kontakt: mila@onlinepsycholog.eu

Škrábová, M., Della Briotta, M. (2021). Bezpečné místo on-line pro Čechy v zahraničí: Bud’te sami sebou i v cizině. E-psychologie, 15(3), 27-31. https://doi.org/10.29364/epsy.412 